\title{
A RARE CASE OF JUVENILE HYPOPHOSPHATASIA
}

FERNANDA BERTUCCI SANCHES (HOSPITAL DA PUC CAMPINAS, CAMPINAS, SP, Brasil), THAIS DE CAMPOS FERREIRA PINTO (HOSPITAL DA PUC CAMPINAS, CAMPINAS, SP, Brasil), IGOR TADEU GARCIA FERREIRA (HOSPITAL DA PUC CAMPINAS, CAMPINAS, SP, Brasil), CLAUDIA VALÉRIA VIERHOUT (HOSPITAL DA PUC CAMPINAS, CAMPINAS, SP, Brasil), NÁDIA REGINA BOSSOLAN SCHINCARIOL (HOSPITAL DA PUC CAMPINAS, CAMPINAS, SP, Brasil), JOSÉ ALEXANDRE MENDONÇA (HOSPITAL DA PUC CAMPINAS, CAMPINAS, SP, Brasil), LUCAS EDUARDO PEDRI (HOSPITAL DA PUC CAMPINAS, CAMPINAS, SP, Brasil), ANDRÉ MARUN LYRIO (HOSPITAL DA PUC CAMPINAS, CAMPINAS, SP, Brasil), RUBENS BONFIGLIOLI (HOSPITAL DA PUC CAMPINAS, CAMPINAS, SP, Brasil), JOSÉ ROBERTO PROVENZA (HOSPITAL DA PUC CAMPINAS, CAMPINAS, SP, Brasil), VANESSA RAMOS GUISSA (HOSPITAL DA PUC CAMPINAS, CAMPINAS, SP, Brasil)

\section{BACKGROUND}

Hypophosphatasia is the rare genetic form of rickets or osteomalacia that presents paradoxically low plasma alkaline phosphatase activity. Juvenile hypophosphatasia is diagnosed after 6 months of age. It occurs premature loss of the primary teeth without pain and without resorption of the root of the teeth, with the root intact. Rickets can cause short stature and delay in gait, deformities can cause valgus knees or varus, brachycephalic skull, skeletal pain and stiffness, non- progressive muscle weakness involving a reeling gait.

\section{CASE REPORT}

A 20-year-old woman referred to the rematologist for presenting frequent fatigue, since childhood, associated with myalgia after physical activity. She reported frequent vomiting, with no apparent cause. She denied fractures, referred to weight-stature development within normality and root syndrome of the teeth. Physical examination without alterations, and complementary tests showed levels of alkaline phosphatase of 5, below the normal value (normal between 40 and 150U/L), and vitamin b6-pyridoxine of 30 (normal between 35 and $110 \mathrm{nmol} / \mathrm{L}$ ).

\section{CONCLUSION}

Bone biopsy shows deficient skeletal mineralization, including non-mineralized skeletal matrix excess (osteoid) that may occur in

points. Radiographs often show pseudofractures, a characteristic of osteomalacia, as well as may reveal generalized osteopenia and

chondrocalcinosis and peri-arthritis by calcification. It appears to improve spontaneously after fusion of growth plates into adult- young life, but recurrence of late symptoms and complications is possible. After the occurrence of fractures, surgical therapy should be instituted. Traditional treatments for rickets and osteomalacia (mineral supplements and vitamin D) should be avoided for this pathology unless specific deficiencies are documented because levels of calcium, phosphorus, and vitamin $D$ metabolites are generally not low.

We have brought the case for the rarity of this pathology, which should be remembered in the differential diagnoses of pathological fractures in the young, dental loss for no apparent reason. Special care should be taken not to use bisphosphonates or unnecessary supplements. 